\title{
Image Brightness Improvement Analysis Using HE, AHE, and ESIHE Comparison Methods
}

\author{
Aditya Akbar Riadi ${ }^{1}$, Ahmad Abdul Chamid ${ }^{2}$ \\ ${ }^{1}$ Program Studi Teknik Informatika, Fakultas Teknik, Universitas Muria Kudus \\ Jl. Lingkar Utara UMK, Gondangmanis, Bae, Kudus, Indonesia e-mail: aditya.akbar@umk.ac.id \\ ${ }^{2}$ Program Studi Teknik Informatika, Fakultas Teknik, Universitas Muria Kudus \\ Jl. Lingkar Utara UMK, Gondangmanis, Bae, Kudus, Indonesia, e-mail: abdul.chamid@umk.ac.id
}

\section{ARTICLE INFO}

Article history:

Received 14 June 2020

Received in revised form 15 June 2020

Accepted 16 June 2020

Available online 31 July 2020

\begin{abstract}
Image improvement is the process of improving the visual quality of images from original images to get better image results. the initial method of image correction is Histogram Equalization (HE) is a technique that is proven to be able to improve image quality, especially the increase in contrast due to simplicity and ease of implementation. In this study the ESIHE technique will be compared with other enhancement techniques, such as Histogram Equalization (HE), Adaptive Histogram Equalization (AHE) from the side of the image results. Next, to assess the even distribution of the histogram, entropy is used to measure the uncertainty associated with the random variable. The aim is to find out which method or technique is the most optimal with the original image. After entropy assessment and analysis, the researcher can conclude that, the ESIHE technique is suitable for comparison of image enhancement with $\mathrm{HE}$ and AHE methods.
\end{abstract}

Keywords: Image Improvement, Exposure SubImage Histogram Equalization, Entropy

\section{Pendahuluan}

Perbaikan gambar adalah proses untuk meningkatkan kualitas visual, dari gambar asli untuk mendapatkan hasil gambar yang optimal. Teknik perbaikan dapat dibagi menjadi dua kategori, mentransformasikan domain dan domain spasial [1]. Kategori pertama, teknik ini beroperasi pada transformasi pemilihan frekuensi dan teknik kedua beroperasi langsung pada tingkat piksel gambar. Histogram Equalization (HE) adalah teknik yang terbukti mampu meningkatkan kualitas gambar, terutama perbaikan kontras untuk kesederhanaan dan kemudahan 
implementasi. Pemerataan histogram meratakan distribusi nilai piksel dan memperluas jangkauan tingkat abu-abu secara dinamis. Ini untuk menambah kontras semua gambar. HE menggunakan Cumulative Density Function (CDF) dari gambar asli untuk menjumlahkan semua probabilitas nilai piksel histogram untuk tingkat gambar yang ditingkatkan. Kelemahan dari HE adalah cenderung mengubah rata-rata kecerahan gambar ke kisaran kecerahan tengah. Sehingga kelemahan ini membuat teknik HE tidak kompatibel untuk sebagian besar elektronik konsumen seperti televisi dan kamera. Beberapa jenis metode telah diusulkan dalam literatur untuk mengatasi kekurangan yang disebutkan di atas. Dalam penelitian [2], usulkan Bi-Histogram Equalization (BBHE) untuk perbaikan kontras menggunakan kecerahan tetap. BBHE membagi histogram menjadi dua bagian berdasarkan kecerahan rata-rata input dan menyamakan dua sub histogram secara independen. Dalam penelitian [3] menggunakan Dualistic Sub-Image Histogram Equalization (DSIHE). Metode ini menghasilkan hasil yang lebih baik daripada BBHE dalam hal meningkatkan kecerahan dan mengukur konten informasi (entropi) dari perbaikan gambar. DSIHE dibagi menjadi dua sub histogram. Mengandung jumlah nilai pixel yang sama dan membaginya dengan median brightness. Tahun-tahun berikutnya, [4] menggunakan Minimum Mean Brightness Error Bi-Histogram Equalization (MMBEBHE) dan pada tahun yang sama melakukan penelitian lagi dan memperkenalkan pendekatan lain bernama Recursive Mean Separate Histogram Equalization (RMSHE) [5]. Kedua metode ini terbukti menemukan nilai optimal dari faktor iterasi merupakan tantangan besar untuk menghasilkan perbaikan yang signifikan. Dalam penelitian [6] menggunakan teknik serupa dengan RMSHE dan dinamakan sebagai Recursive Sub-Image Histogram Equalization (RSIHE).

Tekniknya [2]-[6], tidak menyediakan mekanisme untuk menyesuaikan tingkat perbaikan. Oleh karena itu, dalam penelitian ini kami akan menggunakan algoritma bernama Exposure Sub-Image Histogram Equalization (ESIHE) yang sangat efektif untuk citra skala abuabu pencahayaan rendah dan mempertahankan entropi bersama dengan kontrol pada tingkat perbaikan. Teknik ESIHE yang mencapai nilai maksimum entropi dan kontrol atas proses perbaikan adalah pendekatan yang lebih baik untuk perbaikan gambar pada gambar yang terpapar di bawah. Dalam penelitian ini teknik ESIHE akan ditingkatkan dengan tingkat kecerahan untuk mendapatkan hasil gambar visual. Kemudian ESIHE dibandingkan dengan teknik tambahan lainnya, seperti Histogram Equalization (HE), Adaptive Histogram Equalization (AHE) dari sisi hasil gambar. Selanjutnya untuk penilaian pemerataan histogram, kami akan menggunakan RMSE untuk memprediksi skor kualitas subjektif dengan kesalahan rendah, dan entropi untuk mengukur ketidakpastian terkait dengan variabel acak.

\section{Metodologi Penelitian}

Dalam penelitian ini, ada tiga langkah yang harus diikuti: Langkah pertama adalah perhitungan nilai ambang batas pencahayaan, lalu yang kedua adalah pemotongan histogram, dan langkah terakhir adalah histogram sub division and equalization.

\subsection{Perhitungan Nilai Ambang Batas Pencahayaan}

Pada langkah ini, ditentukan parameter yang disebut ambang pencahayaan [7] yang menunjukkan ukuran intensitas pencahayaan gambar. Parameter yang digunakan untuk membagi gambar asli dengan nilai sub gambar pencahayaan bawah dan atas. Kisaran nilai normal dari nilai eksposur adalah 0-1. Jika nilai eksposur lebih dari 0,5 dan lebih dekat ke 1, itu berarti gambar tersebut mencakup area yang lebih terbuka dan jika nilainya kurang dari 0,5 dan lebih dekat ke 0 maka gambar tersebut dimasukkan di bawah area yang terbuka. Dalam kedua kasus gambar mengandung sedikit nilai kontras yang memerlukan peningkatan kontras. Nilai eksposure intensitas gambar dapat dihitung sebagai berikut 


$$
\text { exposure }=\frac{1}{L} \frac{\sum_{k=1}^{L} h(k) k}{\sum_{k=1}^{L} h(k)}
$$

Di mana $h(k)$ adalah histogram gambar dan L adalah jumlah total tingkat abu-abu. Sedangkan $X a$ yang dihitung dalam persamaan (2) didefinisikan sebagai eksposure, ini adalah sebagai nilai batas level abu-abu yang membagi gambar menjadi sub gambar yang memiliki pencahayaan kurang dan yang memiliki pencahayaan berlebihan.

$$
X_{a}=L(1-\text { exposure })
$$

Parameter ini mencapai nilai lebih besar atau lebih kecil dari L / 2 (tingkat abu-abu) untuk nilai pencahayaan yang lebih rendah atau lebih besar dari 0,5 masing-masing untuk gambar yang memiliki rentang dinamis 0 hingga $\mathrm{L}$.

\subsection{Pemotongan Histogram}

Ide gagasan untuk pemotongan histogram adalah lebih untuk melindungi daripada peningkatan yang mengarah pada penampilan gambar asli. Untuk membatasi laju peningkatan, kita perlu membatasi nilai turunan pertama dari histogram atau histogram asli [8]. Histogram yang memiliki nilai lebih dari ambang pemotongan memiliki ambang batas jumlah yang terbatas, dan dihitung sebagai jumlah rata-rata akurasi tingkat abu-abu. Rumus untuk memotong ambang batas Tc dalam (3) dan (4) menghitung histogram yang terpotong.

$$
\begin{aligned}
& T_{c}=\frac{1}{L} \sum_{k=1}^{L} h(k) \quad \ldots \ldots \ldots \\
& h_{c}(k)=T_{c} \text { for } h(k) \geq T_{c}
\end{aligned}
$$

Di mana $h_{k}$ dan $h_{c}(k)$ adalah histogram asli dan histogram terpotong. Pemotongan histogram dapat menunjukkan komputasi yang efisien dan komputasi yang efisien dan menggunakan lebih banyak waktu.

\subsection{Histogram Sub Division and Equalization}

Dalam langkah ini Histogram Sub Division Equalization [9] adalah histogram asli, yang pertama dibagi dua berdasarkan nilai ambang batas paparan $X_{a}$ sebagaimana dihitung dalam persamaan (2). Proses Sub Divisi Histogram menghasilkan dua sub gambar. $I_{L}$ dan $I_{U}$ mulai dari tingkat abu-abu 0 hingga $X_{a}$ dan $X_{a}+1$ hingga $L-1$ dan dapat disebut sebagai sub gambar yang terpapar dan terpapar berlebihan (Gambar 1). $P_{L}(k)$ dan $P_{U}(k)$ adalah $P D F$ yang sesuai dari sub gambar ini sebagaimana didefinisikan dalam

$$
\begin{aligned}
& P_{L}(k)=\frac{h_{c}(k)}{N_{L}} \text { for } 0 \leq k \leq X_{a} \\
& P_{U}(k)=h_{c} \frac{(k)}{N_{U}} \text { for } X_{a}+1 \leq k \leq L-1
\end{aligned}
$$

Di mana $N L$ dan $N U$ adalah jumlah total piksel dalam sub gambar $I L$ dan $I U$ masingmasing. $C L(k)$ dan $C U(k)$ adalah $C D F$ yang sesuai dari masing-masing gambar dan $C D F$ dapat didefinisikan sebagai

$$
C_{L}(k)=\sum_{k=0}^{X_{a}} P_{L}(k)
$$

TRANSFORMATIKA Vol. 18, No. 1, July $2020: 102-107$ 


$$
C_{U}(k)=\sum_{k=X_{a}+1}^{L-1} P_{U}(k)
$$

Langkah selanjutnya dari ESIHE adalah menyamakan keempat sub histogram secara bertahap. Fungsi transfer untuk pemerataan histogram berdasarkan persamaan (7) dan persamaan (8) dapat didefinisikan sebagai

$$
\begin{aligned}
& F_{L}=X_{a} \times C_{L} \\
& F_{U}=\left(X_{a}+1\right)+\left(L-X_{a}+1\right) C_{U}
\end{aligned}
$$

F_L dan F_U adalah fungsi transfer yang digunakan untuk menyamakan sub histogram secara individual. Langkah terakhir melibatkan integrasi kedua sub gambar ke dalam satu gambar lengkap.

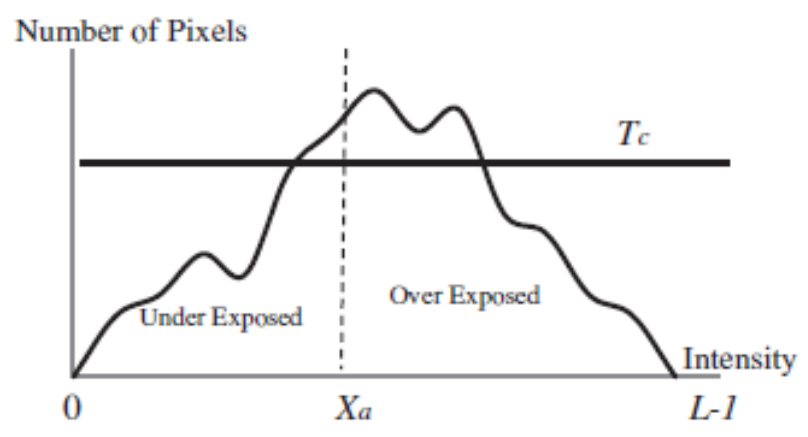

Gambar. 1. Proses Sub Divisi Histogram dan pemotongan nilai ambang batas [9]

Luaran gambar dari ESIHE diperoleh dengan kombinasi kedua fungsi untuk pemeriksaan kualitas visual dan evaluasi kinerja berikutnya.

\subsection{Metode Exposure Sub-Image Histogram Equalization (ESIHE)}

Penjelasan alur dari metode ESIHE dapat mengikuti langkah-langkah di bawah ini:

Langkah 1: Hitung histogram $h(k)$ gambar

Langkah 2: Proses pemotongan histogram,

- Hitung nilai paparan dan parameter ambang $X a$

- Partisi histogram terpotong menjadi dua bagian histogram dengan parameter $\mathrm{Xa}$

Langkah 3: Persamaan Histogram dan Sub Partisi

- Sesuaikan pemerataan histogram pada histogram sub-partisi

- Gabungkan histogram sub partisi menjadi satu gambar untuk dianalisis

\section{Hasil dan Analisa}

Pada bagian ini, hasil simulasi metode ESIHE dibandingkan dengan teknik peningkatan lainnya, seperti HE, AHE. Dataset dikumpulkan dari beberapa sumber media yaitu merupakan data publik.

\subsection{Penilaian Kinerja Menggunakan Perhitungan Entropi}

Perhitungan Entropi ini mengacu pada Entropi Shannon-Fano. Ini adalah hasil dari perhitungan ketidakpastian terkait dengan variabel acak. Ini mengukur tentang informasi yang terkandung dalam sumber informasi seperti gambar. Dalam penelitian ini [10] secara teoritis entropi bernilai tinggi tersedia dari sumber informasi. HE adalah asigen untuk memaksimalkan entropi dengan memetakan kembali level grayscale menggunakan probabilitas level grayscale. Dibenarkan bahwa dengan meningkatkan nilai entropi, gambar dapat mendeklarasikan informasi.

Image Brightness Improvement Analysis Using HE, AHE, and ESIHE Comparison Methods 
Oleh karena itu, gambar dengan entropi bernilai tinggi dianggap memiliki kualitas yang lebih baik. Persamaan (11) dapat digunakan untuk menghitung entropi.

$$
\operatorname{ENT}(p)=\sum_{l=0}^{L-1} P(l) \log P(l)
$$

Dimana $P(l)$ adalah fungsi kerapatan probabilitas dari gambar yang diberikan pada intensitas tingkat 1 dan $L$ adalah jumlah total tingkat abu-abu dari gambar. Gambar dengan nilai entropi tinggi memiliki lebih banyak informasi detail dan dianggap memiliki kualitas yang baik.

Tabel 1. Hasil Perhitungan Entropi dengan Metode yang Berbeda

\begin{tabular}{cllll}
\hline Nama Gambar & Original & HE & AHE & ESIHE \\
\hline Gambar 1 & 5,8484 & 5,3988 & 7,3157 & 5,8251 \\
Gambar 2 & 6,0172 & 5,1293 & 6,9294 & 5,9650 \\
Gambar 3 & 7,2416 & 5,8982 & 7,7940 & 7,2127 \\
Gambar 4 & 5,8211 & 5,2993 & 7,2411 & 5,7946 \\
Gambar 5 & 6,6144 & 5,8816 & 7,7568 & 6,5898 \\
Gambar 6 & 5,8038 & 5,1909 & 7,4040 & 5,7732 \\
Gambar 7 & 7,1238 & 5,9439 & 7,7575 & 7,0600 \\
Gambar 8 & 5,4720 & 4,9192 & 7,1630 & 5,4419 \\
Gambar 9 & 5,1924 & 4,3146 & 6,6306 & 5,1512 \\
Gambar 10 & 6,2175 & 5,6605 & 7,5020 & 6,1789 \\
Rata-rata & 6,1352 & 5,3636 & 7,3494 & 6,0992 \\
\hline
\end{tabular}

Entropi hasil untuk semua metode dan sepuluh data gambar standar ditabulasikan dalam Tabel 1. Beberapa gambar menghasilkan entropi hampir sama dengan gambar asal, seperti gambar 3, gambar 8 dan gambar 9 pada Tabel 1. Hasil entropi gambar 3 memiliki nilai yang berbeda dengan gambar asli, hasil ini adalah 7.2416 untuk gambar asli dan 7.2127 untuk gambar. Teknik ESIHE. Hasil entropi image1 dan image2 memiliki perbedaan hampir satu titik antara gambar asli dengan ESIHE. Rata-rata entropi yang dihasilkan oleh metode HE untuk semua gambar pada Tabel 1 adalah 5.3636, 7.3494 dengan metode AHE dan 6.0992 dengan metode ESIHE. Entropi hasil menggunakan metode ESIHE sangat dekat dengan rata-rata entropi untuk gambar asli adalah 6.1352. Entropi lebih dekat dengan gambar asli dan memberikan jaminan informasi konten gambar lebih maksimal.

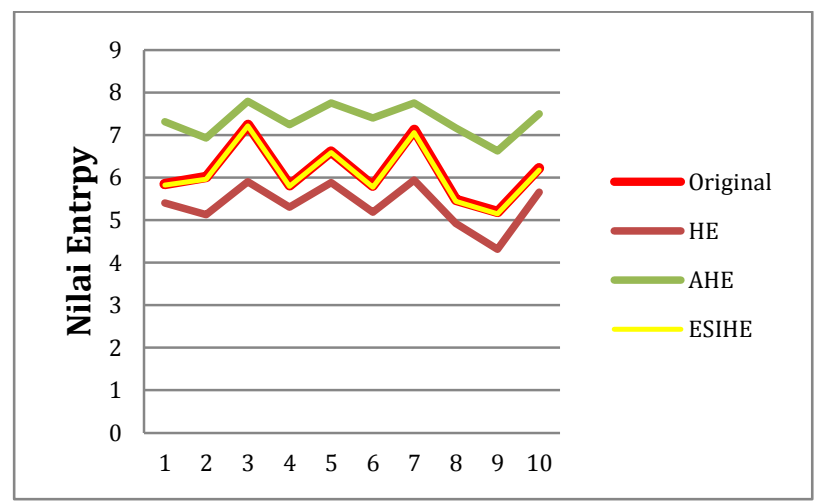

Gambar 2. Grafik Perhitungan Nilai Entropi

Pada grafik yang ditunjukkan oleh gambar 2 dimana terlihat metode ESIHE memilki nilai yang mendekati nilai entropi dari gambar original atau aslinya. Itu menunjukkan bahwa metode ESIHE lebih optimal dibandingkan dengan metode HE dan AHE.

TRANSFORMATIKA Vol. 18, No. 1, July $2020: 102-107$ 


\section{Kesimpulan}

Dalam tulisan ini, kami mencoba membandingkan tiga teknik untuk peningkatan gambar. Ada HE, AHE dan ESIHE. Setiap teknik menunjukkan kinerja yang berbeda. Untuk mengevaluasi setiap teknik, kami menggunakan penilaian kinerja hasil perhitungan entropi. Berdasarkan entropi hasil dan kualitas visual, ESIHE menunjukkan peningkatan gambar hasil lebih optimal jika dibandingkan dengan HE dan AHE. Kualitas gambar visual dari masingmasing teknik menunjukkan kekuatan metode dan keunggulan pada metode lain untuk berbagai jenis gambar. Kualitas gambar visual dapat ditingkatkan dengan tingkat kecerahan pada gambar asli. Dalam penelitian ini dapat disimpulkan sebagai berikut:

1. Teknik ESIHE adalah metode yang baik dan cocok untuk peningkatan gambar dibandingkan dengan HE dan AHE.

2. Teknik ESIHE menghasilkan entropi lebih dekat ke gambar asli dibandingkan HE dan AHE.

3. Tingkat Kecerahan yang diterapkan dalam teknik ESIHE dapat meningkatkan kinerja gambar visual.

4. Teknik ESIHE menghasilkan lebih sedikit kesalahan dibandingkan dengan dua teknik, seperti HE dan AHE, meskipun peningkatan hasil gambar secara visual lebih detail dan kontras yang baik saat diproduksi dengan AHE.

\section{Referensi}

[1] R. Gonzalez and R. Woods, Digital image processing. Prentice Hall. 2002.

[2] Y. T. Kim, "Contrast enhancement using brightness preserving bi-histogram equalization," IEEE Trans. Consum. Electron., 1997, doi: 10.1109/30.580378.

[3] Y. Wang, Q. Chen, and B. Zhang, "Image enhancement based on equal area dualistic subimage histogram equalization method," IEEE Trans. Consum. Electron., 1999, doi: 10.1109/30.754419.

[4] S. Der Chen and A. R. Ramli, "Contrast enhancement using recursive mean-separate histogram equalization for scalable brightness preservation," IEEE Trans. Consum. Electron., 2003, doi: 10.1109/TCE.2003.1261233.

[5] S. Der Chen and A. R. Ramli, "Minimum mean brightness error bi-histogram equalization in contrast enhancement," IEEE Trans. Consum. Electron., 2003, doi: 10.1109/TCE.2003.1261234.

[6] K. S. Sim, C. P. Tso, and Y. Y. Tan, "Recursive sub-image histogram equalization applied to gray scale images," Pattern Recognit. Lett., 2007, doi: 10.1016/j.patrec.2007.02.003.

[7] M. Hanmandlu, O. P. Verma, N. K. Kumar, and M. Kulkarni, "A novel optimal fuzzy system for color image enhancement using bacterial foraging," 2009, doi: 10.1109/TIM.2009.2016371.

[8] C. H. Ooi, N. P. Kong, and H. Ibrahim, "Bi-histogram equalization with a plateau limit for digital image enhancement," IEEE Trans. Consum. Electron., 2009, doi: 10.1109/TCE.2009.5373771.

[9] K. Singh and R. Kapoor, "Image enhancement using Exposure based Sub Image Histogram Equalization,” Pattern Recognit. Lett., 2014, doi: 10.1016/j.patrec.2013.08.024.

[10] S. Der Chen, "A new image quality measure for assessment of histogram equalizationbased contrast enhancement techniques," Digit. Signal Process. A Rev. J., 2012, doi: 10.1016/j.dsp.2012.04.002. 